\title{
Where Does the Time Go?
}

\section{"The bad news is, time flies. The good news is, you're the pilot."}

can't believe it's been almost a full year since Past President Al Stinson welcomed me as President of the CIF/IFC in Kenora, Ontario. Time flies and I had such high expectations of myself in this role... Having served as President in other organizations, I promised myself that, this time, I would use my brief time more strategically to create a positive impact. And yet here I am (again) wondering if I was able to make a difference?

I believe the most important role of a leader is to surround oneself with great people and then serve them by providing direction and removing barriers. By that measure, our National Executive has done well. We've been busy this year, working with our Executive Director, Dana Collins, and our National Board to provide that strategic direction and then implement strategies which drive us towards our goals.

We developed five Key Strategic Areas and have worked hard to focus our efforts for maximum effect. Over the last year, the following achievements are something we can all be proud of:

1. Providing Value to Members through the delivery of an effective forestry continuing education and professional development program. This included leadership in forestry communications (such as infographics about the "Myth of Deforestation" and "Benefits of Urban Forestry"), delivering over 40 e-Lectures, publishing the Chronicle, developing a bridge-training program for OPFA and being selected as the delivery agent for Ontario's Silvicultural Tree Marking Program.

2. Ensuring Financial Stability by growing our membership ranks (individual and organizational) and targeting an annual surplus. We are projecting to meet (or exceed) our budgeted surplus position through a diversification of revenues and prudent fiscal management by our Budget Committee and we've been actively growing our Reserve Fund from our modest surpluses.

3. Promoting Professionalism by being the forum of choice for connecting forest professionals, practitioners, teachers and the environmentally minded public (including youth). We were active in supporting regional teacher tours and Envirothons and continue to lead by example with our new Silver Ring philosophy to unite the profession.

4. Achieve National and International Profile by being recognized as the national voice of Canadian Forestry. We have grown our relationships with China, USA and the UK and, for the first time ever, now have an active International Section with a Director that attends National Board meetings. This enhanced profile led the International Energy Agency look to the CIF/IFC to develop and coordinate a series of webinars for international outreach.

5. Promote Forestry Awareness and Public Outreach by being visible, timely and relevant to the public. We coordinated over 15000 posters and

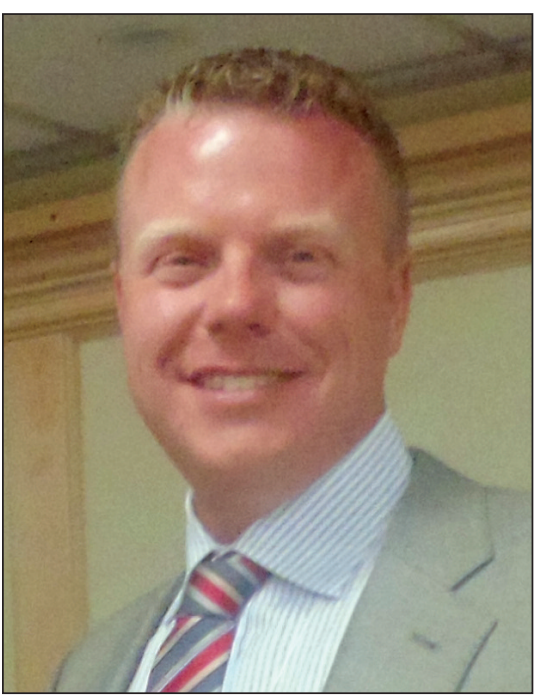

Jonathan Lok, RFT CIF/IFC President/président

200 events for National Forest Week, prepared media releases, editorials and other communication and even had a commercial playing at the Montreal Grand Prix.

In addition, we've been working on refining our policy governance at the CIF/IFC to improve effectiveness and efficiency of how we work, and to better navigate organizational risk. While not the most thrilling topic-it's one that will hold long-term benefit for the entire CIF/IFC, our Board members and our staff.

I'm proud of what we've accomplished this past year and look forward seeing everyone at the Conference in Vancouver in September!

\section{Ah! Que le temps passe vite! " La mauvaise nouvelle est que le temps s'envole. La bonne nouvelle est que vous êtes le pilote. ”}

e n’arrive pas à croire qu'il s'est écoulé presque toute une année depuis que le président sortant, Al Stinson, ma souhaité la bienvenue en tant que président de l'Institut à Kenora en Ontario. Le temps file et mes ambitions étaient très élevées lorsque je suis entré en poste... Comme javais déjà été président d'autres organisations, je métais promis que, cette fois-ci, jallais utiliser cette brève période de façon plus stratégique afin d'apporter des changements posi- tifs. Et me voici, encore une fois, en train de me demander si j’ai été en mesure de faire quelque chose de vraiment différent.

J'ai la ferme conviction qu'un vrai leader doit d'abord s'entourer de gens 
hors de lordinaire, leur indiquer la voie à suivre et éliminer les obstacles sur leur chemin. En ce sens, le bureau de direction nationale a bien travaillé cette année. Avec le concours de notre directrice générale, Dana Collins, et celui du conseil d'administration de l'Institut, nous avons consacré beaucoup de temps à définir et à mettre en place les orientations stratégiques qui nous auront permis datteindre nos objectifs.

Nous avons retenu cinq domaines stratégiques principaux et $\mathrm{y}$ avons consacré tous nos efforts pour maximiser les résultats. Voici donc les réalisations de cette année dont nous sommes très fiers :

1. Représenter une valeur ajoutée pour nos membres par la réalisation d'un programme efficace de formation continue et de croissance professionnelle en foresterie. Nous avons fait preuve de leadership en matière de communication en foresterie (entre autres avec les infographies sur « Le mythe de la déforestation " et "Les bienfaits de la foresterie urbaine », organisé plus de 40 conférences électroniques, avons publié le Chronicle, élaboré un programme de formation complémentaire pour l'OPFA et avons été choisi comme mandataire du programme de marquage des arbres pour les projets sylvicoles de l'Ontario.
2. Assurer la stabilité financière de l'IFC/CIF en augmentant le nombre de membres (individuels et organisationnels) et en visant un excédent budgétaire annuel. Nous envisageons d'atteindre (ou de dépasser) nos objectifs budgétaires par une diversification des revenus, une gestion budgétaire prudente effectuée sous la direction par le comité des Finances et avons réussi à accroître notre fonds de réserve grâce à un modeste excédent annuel.

3. Promouvoir le professionnalisme en étant le principal forum par excellence pour relier entre eux les professionnels de la foresterie, les praticiens, les enseignants et le public concerné par l'environnement (incluant les jeunes). Nous participons activement à lélaboration d'excursions techniques pour les enseignants ainsi quau programme Envirothon et nous continuons de donner l'exemple avec notre nouvelle philosophie sur les joncs d'argent qui vise à unir les membres de la profession.

4. Être reconnu au plan national et international comme la voix officielle de la foresterie au Canada. Nous avons développé nos relations avec la Chine, les É.-U. et le R.-U. et pour la première fois, nous avons créé une section internationale dont le directeur est invité aux réunions du conseil d'administration. Cette plus grande visibilité a fait en sorte que l'Agence internationale de l'Énergie a retenu l'IFC/CIF pour élaborer et coordonner une série de webinaires de portée internationale.

5. Promouvoir la sensibilisation à l'importance de la foresterie au sein du public en étant visible, informé et pertinent à ses yeux. Nous avons coordonné quelque 200 activités et la distribution de plus de 15000 affiches dans le cadre de la Semaine nationale de larbre et des forêts, préparé des communiqués de presse, des éditoriaux et d'autres textes, en plus davoir fait tourner une publicité lors du Grand Prix de Montréal.

De plus, nous avons reformulé la politique de gouvernance de l'IFC/CIF afin dêtre plus efficaces et efficients dans notre façon de travailler et ainsi nous permettre déviter les écueils administratifs. Même s'il ce n'est pas le sujet le plus passionnant-c'est celui qui apporte le plus d'avantages durables pour l'Institut, pour les membres de son conseil d'administration et pour le personnel de l'IFC/CIF.

Je suis fier de ce que nos réalisations de la dernière année et j’ai hâte de vous rencontrer tous lors de la conférence de Vancouver en septembre!

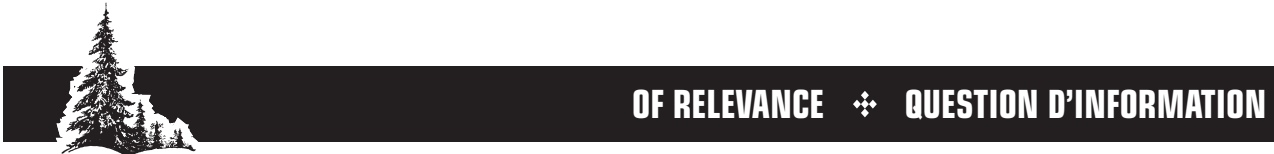 How to Write a Journal Article: Tips and Tools
}

\author{
Sarah Boon, Ph.D. ${ }^{1}$
}

If you've trained as a scientist, you know that part of the learning curve involves figuring out how to write a scientific paper. Unfortunately, few scientists receive explicit instruction in writing papers-researchers by definition are expected to know how to write. When you're a grad student, your supervisor is there to guide you through the paper publication process, as it's in their best interests to have you publish the outcome of your research with them. Once you become an independent scientist, however - whether that's in academia, industry, or at an $\mathrm{NGO}$-writing research papers can be a frustrating and lonely experience.
There are many online resources and excellent books designed to provide writing advice to scientists. The difficulty as an early career researcher lies in making the time to learn how to write a good paper while also teaching yourself $\mathrm{R}$ stats and maybe a bit of Bayesian statistical methods, coming up with new pedagogical approaches to engage your studentsor figuring out how to manage a work team, applying for a shrinking pot of grant funds, starting up a lab or getting familiar with a new job.

This post distills the process of writing a paper into the key steps, and provides links to additional resources available.

${ }^{1}$ Sarah Boon blogs at Watershed Moments about nature, nature writing, science communication, and women in science. She is a member of the Canadian Science Writers' Association and the Editors' Association of Canada, and was elected a Fellow of the Royal Canadian Geographical Society in 2013. Sarah is also a founding member of Science Borealis. Find Sarah on Twitter: @SnowHydro 